\title{
PERSPEKTIF JARINGAN PERTUKARAN MARITIM TERHADAP SUMBER-SUMBER PANGAN DI PULAU-PULAU KECIL, KABUPATEN WAKATOBI SULAWESI TENGGARA
}

\author{
La Ode Rabani* dan Adhi Rahman B** \\ E-mail: laode-rabani@fib.unair.ac.id \\ *Departemen Sejarah Fakultas Ilmu Budaya Universitas Airlangga \\ **Program Studi Teknik Lingkungan, Fakultas Sains dan Teknologi, Universitas
}

\begin{abstract}
This article analyzes the sources of foods in small islands from the maritime exchange network perspective. The location of the research was a group of small islands in Southeast Sulawesi. This research found that resources of food in the small islands came from the other region as the part of process of exchanges maritime networks, especially from the Wallacean line connection and other main islands of Indonesia. Process and its form become local culinary, were other a part of the creative process, and the expression of its citizens. Some supporting tools for processing resources of food also identified as an invention from the local society have been fully health standards. To support that argument, the authors identifying the origins of food resources, processing, and preserving strategies. Knowledge about the food resources on the small islands contributes to the understanding of the globalization connections in small Islands, a wider world at the local level.
\end{abstract}

Record of Article

Received : 26 Mei 2020

Revised : 5 Juli

Accepted : 21 Agustus 202

Key word: food resources, Wallacean line network, maritime perspective, small Islands, Wakatobi. 


\section{PENGANTAR}

Data faktual mengenai pulau-pulau kecil sebagaimana laporan BPS tentang statistik Kabupaten Wakatobi (sebelumnya; Kepulauan Tukang Besi) menunjukkan bahwa hanya ada 3 persen wilayah daratannya dari empat pulau utama, yakni Wanci, Kaledupa, Tomia, dan Binongko. Data itu memberi informasi bahwa kawasan pulaupulau kecil itu memiliki wilayah laut 97 persen dari total luas wilayah $473,62 \mathrm{~km}^{2}$ (Statistik, 2019, pp. 1-3). Kenyataan lain dari keempat pulau adalah wilayah daratannya tidak semuanya mempunyai tanah subur, melainkan sebagian besarnya adalah batu kapur. Kenyataan itu memberi makna bahwa hanya sebahagian kecil saja yang dapat dijadikan lahan pertanian sebagai sumber karbohidrat penduduknya. Jumlah penduduk kawasan pulau-pulau kecil itu adalah 95.892 jiwa yang artinya setiap kilometernya dihuni oleh 202 orang. Pulau Wangi-Wangi memiliki banyak penduduk dan pulau Binongko paling sedikit penduduknya. Pulau Kaledupa dan Tomia jumlah penduduknya tidak sebanyak pulau Wangi-Wangi. Data kenaikan jumlah penduduk juga relatif tinggi yakni 0, 16 persen/tahun, sehingga secara teoritis, penduduk di gugusan pulau tersebut terus mengalami peningkatan setiap tahunnya (Statistik, 2019, p. 62).

Menurut data koran yang diterbitkan pada masa pemerintahan Belanda tahun 1930an menunjukkan bahwa hanya ada dua pulau yang mempunyai sumber daya air bersih dan layak dikonsumsi, yakni pulau Wanci atau Wangi-Wangi dan Kaledupa. Pulau Tomia dan Binongko memiliki sumber air yang sangat terbatas (De Sumatra post, 26 Mart 1931). Di dua pulau itu (Wangi-Wangi dan Kaledupa, tumbuh tanaman rempah-rempah dan juga aneka bahan pangan lainnya, termasuk padi, meskipun tidak sebaik tanaman padi yang ada di Jawa, Sulawesi Selatan, daratan Kendari (Wawotobi), dan Sulawesi Tengah (Luwuk) dari sisi produksi (Rabani, 2016). Data itu memberi indikasi adanya kekurangan pangan, khususnya dalam pemenuhan sumber karbohidrat, sehingga pertukaran, mobilitas, dan impor dari dan dengan wilayah lain yang menyediakan sumber pangan menjadi kebutuhan utama.

Studi tentang pulau-pulau kecil di dunia lebih difokuskan pada ketahanan pangan (food security)di tingkat lokal (Barlagne et al., 2015; Juliana, n.d.; Lutz \& Schachinger, 2013) dan mitigasi (Pascali, 2017; Wibowo, 2015; Grydehøj \& Kelman, 2017). Kedua aspek itu berkaitan dengan kerentanan kawasan pulau-pulau kecil dari bencana gelombang tinggi dan pemanasan global. Dari sisi ketahanan pangan, penelitian diarahkan pada ketersediaan bahan makanan bagi masyarakat pulau-pulau kecil. Kajian itu difokuskan pada pulau-pulau yang ada di pasifik, Kepulauan Fiji, dan 
Solomon (Cleasby et al., 2014; Shah et al., n.d.). Kawasan kepulauan itu menjadi ruang riset tentang pulau-pulau kecil.

Penelitian tentang kawasan pulau-pulau kecil, Kepulauan Tukang Besi (Wakatobi) sejauh ini berfokus pada tradisi, pelayaran dan perdagangan. Catatan sejarah Wakatobi yang diungkap dalam penelitian itu berasal dari Ali Hadara (1987), La Malihu (1998), Abdul Rahman Hamid (2010, 2010; Tahara et al., 2015), dan Hans-Dieter Evers (Evers, 1988) sama-sama mengakui tradisi pelayaran dan perdagangan masyarakat Wakatobi kuat karena hingga tahun 1980an, perahu dan kapal motor di kawasan itu sangat banyak dan seringkali melakukan pelayaran dan perdagangan antar pulau-pulau utama di berbagai wilayah Nusantara hingga ke Malaysia dan Singapora. Demikian juga catatan dari A.R. Wallace (Wallace, 2010) dalam perjalanannya ke Maluku mencatat bahwa ketika melewai selat Wangi-Wangi, kapalnya dilewati oleh perahu yang menuju ke pulau Wanci. Penelitian La Ode Rabani (1997b) tentang migrasi dan perkembangan sosial ekonomi yang didorong oleh aktivitas pelayaran dan perdagangan. Aspek lain yang diteliti mengenai kawasan ini adalah penyelundupan dan terbentuknya kawasan ekonomi dengan basis pemikiran yang sama-sama didorong oleh aktivitas mobilitas melalui pelayaran dan perdagangan (Rabani, 2019). Dengan melihat studi-studi di atas, maka aspek pertukaran maritim dan sumber-sumber pangan yang menjadi kebutuhan dasar masyarakat satu kawasan kepulauan Tukang Besi/Wakatobi belum hadir dalam ranah ilmu pengetahuan, sehingga artikel ini kehadirannya untuk mengisi kekosongan tersebut. Pada saat yang sama, artikel ini bisa menjadi dasar bagi studi-studi selanjutnya atau kawasan pulau-pulau kecil lainnya yang mempunyai corak yang sama.

Dalam kaitan itu, satu indikasi kuat yang menyebabkan terbentuknya pertukaran dan mobilitas adalah adanya efek/kondisi ekologi yang tidak memungkinkan pengembangan lingkungan yang menjamin tersedianya bahan untuk pememenuhan kebutuhan pangan dasar masyarakatnya. Pada saat yang sama, solusi rasional untuk menutupi kekurangan sumber pangan adalah mendatangkannya dari luar dengan beragam metode, salah satu di antaranya adalah pertukaran. Artikel ini mengidentifikasi dan menganalisis bagaimana jaringan pertukaran maritime menjadi solusi paling mudah dilakukan dalam menunjang pemenuhan kebutuhan pangan di pulau-pulau kecil, seperti di Kepulauan Wakatobi. Untuk menjawab pertanyaan itu, artikel ini dimulai dengan identifikasi bahan-bahan pangan apa saja yang tersedia di Wakatobi? Dari mana dan bagaimana sejarah dari bahan pangan itu sampai di Wakatobi? Bagaimana bahan pangan itu diberi identitas dan seni sehingga memiliki nilai tradisi pada level lokal? Bagaimana kemungkinan pengembangannya dengan penggunaan teknologi lingkungan terkini sebagai strategi mempertahankan makanan yang diakui masyarakatnya sebagai bagian dari tradisi lokal? 


\section{ALAM WAKATOBI: KEPULAUAN TANDUS YANG KAYA PROTEIN HEWANI}

Nama Wakatobi baru popular sejak tahun 2003, ketika menjadi nama sebuah Kabupaten di Sulawesi Tenggara. Studi La Ode Rabani (1997b) menelusuri akar penamaan Wakatobi yang ternyata sudah ada sejak 1960an ketika para pelajar dan mahasiswa Wakatobi menyelenggarakan kongres dan merumuskan nama dari organisasi pelajar dan mahasiswa yang didirikan. Sebagian tokoh-tokoh yang merumuskan dan melahirkan istilah Wakatobi adalah La Ode Bosa dari Wanci dan La Ode Usman dari Kaledupa. Saat ini, nama Wakatobi lebih dimaknai sebagai rangkain dua akronim awal dari nama empat pulau utama, yakni pulau (Wa)nci, (Ka)ledupa, (To)mia, dan (Bi)nongko (Hadara, 2015; Hadara, dkk., 2014; Rabani, 1997a). Dengan penamaan seperti itu, proses historis menjadi Wakatobi ikut tereduksi.

Alfred R. Wallace tidak pernah membayangkan kalau melewati sisi kanan selat Wangi-wangi dalam perjalanannya ke Kepulauan Maluku ada lebih dari 700an spesies ikan di bawah laut. Kini Kawasan ini telah menjadi bagian dari segitiga karang dunia dan telah ditetapkan oleh Organisasi PBB, UNESCO sebagai cagar biosfer dunia "Coral Tri-Angle Center". (Statistik, 2016; Utomo, 2012). Pemerintah Belanda yang melakukan pemetaan atas kawasan Wakatobi untuk mengukur temperature laut, kedalaman, kandungan garam, dan gas dengan jelas memperlihatkan karang-karang (lihat map) yang mengelilingi Wakatobi (Stok, 1922, pp. 92, 333-335). Karang-karang itulah yang menjadi ruang singgah dan ruang berkembangbiaknya 700an spesies ikan yang ada di gugusan Kepulauan Wakatobi. Kondisi itu berbanding terbalik dengan produk daratnya sebagai penyedia bahan pangan. Atas dasar itulah alam Wakatobi lebih tepat disebut rumah ikan dunia, karena ragam jenis ikan yang menghuninya.

Alam Wakatobi yang "miskin" bahan pangan agraris telah membuka ruang mobilitas bagi masyarakat untuk mengembangkan tradisi baru. Tradisi itu adalah bagaimana menyediakan dan mengembangkan bahan makanan bagi orang-orang Wakatobi. Mobilitas sirkuler dalam bentuk pelayaran dan perdagangan menjadi salah satu yang dikembangkan. Sejarah pelayaran orang-orang Wakatobi menurut Ali Hadara telah berlangsung lama (Hadara, 1987). Tujuan dari pelayaran itu adalah peningkatan ekonomi dan pemenuhan kebutuhan rumah tangga/keluarga. Apabila ada kelebihan, maka akan dijual. Jenis bahan pangan yang didatangkan dari pelayaran dan perdagangan adalah beras, jagung, dan umbi-umbian. Umbi-umbian yang dibawa ke Wakatobi, ada yang ditanam dan dikembangkan secara terus menerus, yang hasilnya untuk persediaan makanan. Kebiasaan keluarga dalam masyarakat Wakatobi sering kali berbagi bibit untuk ditanam di lahan-lahan yang mudah tumbuh sehingga cepat panen atau dijadikan bibit untuk ditanam kembali saat musim hujan. 


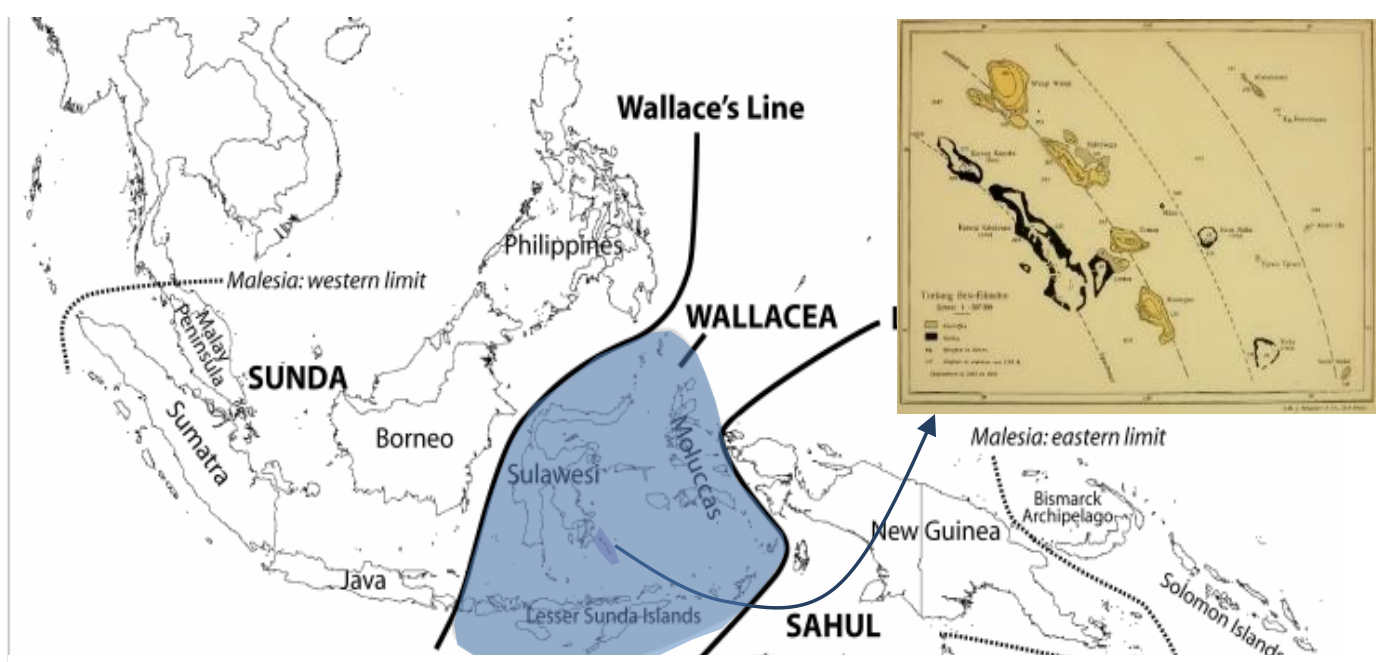

Gambar 1 Wakatobi dan Wallacea Line's dalam peta Indonesia.

Sumber: diolah dari Peter C. van Welzen, John A. N. Parnell, J. W. Ferry Slik, “Wallace's Line and plant distributions: two or three phytogeographical areas and where to group Java? "Biological Journal of the Linnean Society" vol. 103, 3. 2011, p. 532.

Perjuangan panjang orang-orang Wakatobi dalam pemenuhan kebutuhan bahan pangannya diketahui ketika mengidentifikasi sejumlah jenis pangan yang dikonsumsi mereka. Hasil identifikasi menunjukkan bahwa bahan pangan mereka berasal dari daerah-daerah yang biasa datangi, khususnya di pantai Timur Sulawesi, kepulauan Xula (Banggai, Labobo, Bangkulu, Taliabu, Sulabes, Mangoli, Buru), Ambon, dan Kepulauan Maluku. Masyarakat Wakatobi datang ke daerah-daerah tersebut untuk mengisi sektor perkebunan dan pedagang informal kota dan desa. Pada saat yang sama mereka juga secara aktif melakukan penanaman di sela-sela tanaman perkebunan yang mereka jaga. Hasil dari aktivitas penanaman dan budidaya itu dikirim ke Wakatobi dalam bentuk bahan pangan dan sebagian lainnya sebagai bibit untuk ditanam. Melalui proses itu, sumber pangan yang ada di daerah lain masuk ke Wakatobi. Menurut catatan Boomgaard, (Boomgaard, 2003; Guillaud, 2015) bahan pangan seperti talas dan keladi telah lama dikembangkan dan telah menjadi bahan pangan utama di kepulauan Xula. Bahan pangan yang sama telah menjadi bahan pangan utama di Wakatobi. Itu berarti bahwa relasi antara kepulauan Xula dan pulau-pulau kecil di Wakatobi adalah memiliki bahan pangan yang sama. Dalam konteks itu, penulis memandang bahwa bahan pangan itu berasal dari kawasan yang sama, kepulauan Xula (Rabani, 2013). Kawasan itu dalam catatan sejarah sebagaimana diakui J.C van Leur sebagai jaringan pelayaran dan perdagangan antar-pantai di kepulauan Nusantara (Leur, 1953). Pola pelayaran lama, dari pulau satu ke pulau lain tampaknya menjadi pola utama karena 
alasan pemenuhan logistik dan perlindungan dari beragam gangguan yang sewaktuwaktu terjadi dalam proses dan misi pelayaran dan perdagangan.

\section{JARINGAN PERTUKARAN MARITIME DAN RAGAM BAHAN PANGAN}

Data jaringan pertukaran maritim yang berlangsung di Wakatobi dapat diidentifikasi melalui rekaman pelayaran perahu yang ada di kawasan itu. Data wawancara yang dilakukan pada tahun 2014 dengan La Dimani dan La Mananu mengatakan hal yang sama tentang rute pelayaran dan perdagangan yang dilalui ke Indonesia timur. Barang-barang yang diambil pun selain komoditas utama perdagangan berupa rempah-rempah jenis cengkeh dan pala, juga membeli bahan pangan untuk bekal selama perjalanan dan dibawa pulang ke Wakatobi. Jenis bahan pangan yang diambil adalah keladi, talas, opa, manga (dari jenis umbi-umbian), dan kelapa. Pada umumnya, bahan-bahan itu memiliki daya tahan lama, sehingga bisa dibawa dan ditanam di Wakatobi. Cengkeh, pala, dan kopra biasanya dijual ke Surabaya, Baubau, dan Makassar.

Kota Makassar dan Surabaya adalah dua pusat pemasaran komoditas dan pusat produksi bahan-bahan kebutuhan rumah tangga. Jadi muatan perahu berupa komoditas yang dikumpulkan dari kepulauan Maluku disinggahkan di Wakatobi, lalu dipasarkan di Makassar dan atau Surabaya. Dalam perjalanan pulang dari Surabaya atau Makassar, para pedagang dan pelayar itu memuat barang kebutuhan rumah tangga dalam beragam jenis, termasuk pakaian untuk diperdagangkan antar pulau. Mereka singgah di Bima, Sumbawa, Rote, Selayar, dan menuju Kabaena, Wakatobi. Perjalanan dari Kepulauan Maluku ke Jawa hanya bisa dilakukan pada angin musim timur dan maksimal dilakukan hanya dua kali dalam 1 tahun. Hal itu terjadi karena mengandalkan angin sebagai tenaga penggerak perahu untuk mencapai berbagai tujuan (Wawancara dengan H. La Dimani dan La Mananu, 2014 di Wanci). Dalam perjalanan pertama dari Jawa, orang-orang Wakatobi selalu singgah di Wakatobi sebelum melakukan perjalanan memuat rempah-rempah dan atau kopra di Kepulauan Maluku. Posisi Wakatobi di jalur perdagangan dan berada pada lintasan pusat produksi rempah dan pusat produksi barang-barang bahan jadi di Makassar dan Jawa ikut mendukung mobilitas sirkuler yang dilakukan masyarakat. Mobilitas sirkuler ini tidak berlangsung lama, karena sangat tergantung pada angin. Akan tetapi itu cukup untuk menjaga keseimbangan persediaan pangan masyarakat. Sumber pangan yang rutin berasal dari Baubau dan atau dari pulau Buton. Pada tahun 1960an ketika sumber pangan sangat terbatas di Wakatobi, masyarakat melakukan migrasi ke kepulauan Maluku untuk memperoleh bahan pangan. Bahan pangan itu adalah sagu dan umbi-umbian yang berasal dari Larantuka Nusa Tengara Timur. Sebagian lainnya adalah umbi-umbian 
yang berasal dari daratan pulau Buton yang dikenal beracun. Demikian juga bahan pangan utama masyarakat adalah jenis singkong beracun yang hanya bisa dikonsumsi setelah mengalami proses pengolahan yang rumit, mulai diparut, dikemas dan keringkan airnya selama 10 jam, lalu digemburkan, untuk selanjutnya dikukus, baru bisa dikonsumsi (Rabani, 1997b).

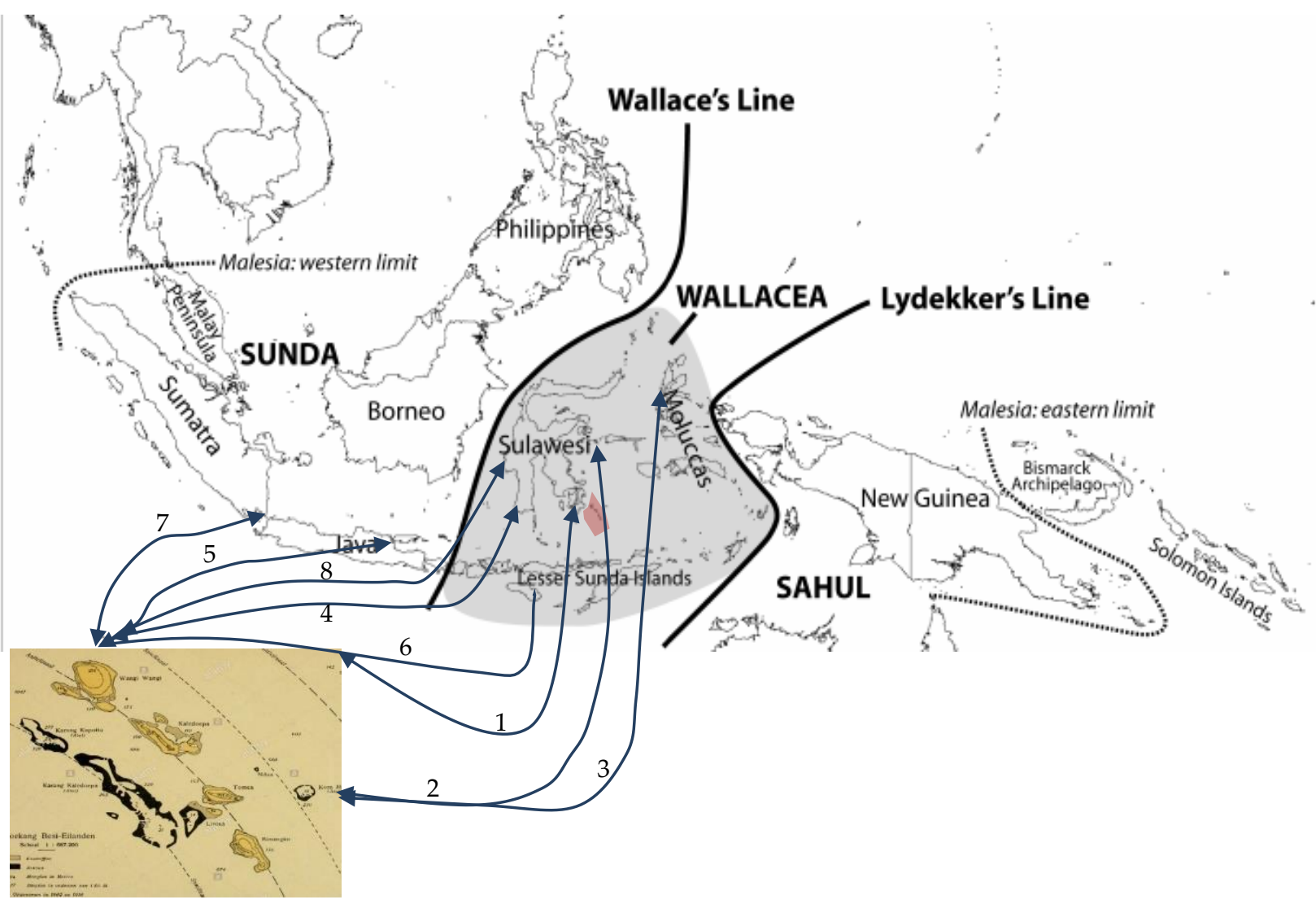

Gambar 2 Jaringan persebaran sumber pangan ke Kepulauan Wakatobi

Sumber: Peta dilah dari Peter C. van Welzen, John A. N. Parnell, J. W. Ferry Slik, "Wallace's Line and plant distributions: two or three phytogeographical areas and where to group Java? "Biological Journal of the Linnean Society" vol. 103, 3. 2011, p. 532.

\section{Keterangan Peta}

1. Jalur Pulau Buton: Umbi-umbian dan beras/padi

2. Jalur ke Pantai Timur Sulawesi dan Kepulauan Sula: Talas dan Umbi-umbian

3. Jalur Ke Kepulauan Maluku: mangga dan kelapa

4. Jalur Makassar: Mangga, beras, dan kelapa

5. Jalur ke Jawa: Singkong

6. Jalur ke Rote: gula (gula aren dari enau) 
7. Jalur ke Malaka: buah (Malaka==Jambu Biji)

8. Jalur ke Mandar, Sulawesi barat: Ubi jalar-mandara

Jejak pangan Wakatobi yang berasal dari Nusa Tenggara adalah umbi-umbian berbentuk oval. Orang setempat menyebut dengan “opa Larantuka”. Dari pulau Jawa, tampaknya singkong menjadi pangan utama masyarakat Wakatobi. Hal itu ditandai dengan sebutan singkong dengan "kayu Jawa". Jaringan ke Malaka, orang-orang Wakatobi membawa buah jambu biji dengan menamakannya dengan "Bua(h) Malaka. Dalam jaringan ke Mandar, orang-orang Wakatobi memperoleh ubi jalar. Dalam bahasa setempat dinamakan dengan "mandara". Jaringan ke Kepulauan Maluku mereka memperoleh mangga yang enak. Orang-orang Wakatobi menyebutnya dengan nama “po'o Jojolo (Jailolo). Nama depan Po'o berasal dari serapan bahasa Bugis. Nama po'o ini telah dikonfirmasi dengan salah satu ahli naskah Bugis Lontara, Anna yang bekerja di Arsip Sulawesi Selatan. Jaringan ke Makassar, orang-orang Wakatobi memperoleh beras dan mangga yang enak juga. Orang Wakatobi menyebut dengan nama bae bugisi (beras Bugis) dan po'o jupanda (mangga dari Ujung Pandang), Po'o Karae(ng) (Mangga Karaeng), dan juga kelapa.(Rabani, 2013) Dalam bahasa Bugis dan Wakatobi, kelapa sama-sama disebut kaluku. Gula juga diperoleh dari Sulawesi Selatan, dengan menamakannya "gola Bone" (Gula dari Bone).

Dengan data-data di atas, jaringan pertukaran Maritim Wakatobi dapat digambarkan dalam peta berikut. Jaringan itu menampakkan pertukaran maritim karena perbedaan sumber daya dan keahlian orang-orang Wakatobi dipaksa oleh alam untuk menguasai teknik navigasi untuk bisa menjangkau wilayah yang lebih luas dengan semangat pemenuhan kebutuhan pangan dan meningkatkan ekonomi keluarga di tengah keterbatasan alamiah. Orang-orang di bagian lain Kepulauan Wakatobi seperti Lasalimu, Kambowa, Mawasangka, Wawonii, Menui, Bungku, Banggai, dan sekitarnya memiliki sumber daya melimpah, sehingga antar komunitas, saling berkontribusi menciptakan pasar dan melakukan aktivitas pertukaran. Aktivitas pertukaran paling dominan dilakukan melalui laut untuk memindahkan komoditas dan barang dari satu daerah ke daerah lain. Bahan-bahan itu diolah untuk beragam keperluan, termasuk untuk kebutuhan tradisi dalam masyarakat Wakatobi.

\section{SUMBER PANGAN DARI WILAYAH GARIS WALACEA: PENGOLAHAN, IDENTITAS DAN PENGOLAHANYA DI Wakatobi}

Sumber pangan yang tersebar di garis Wallacea sebagian besar adalah jenis bijibijian dan umbi-umbian. Dari biji dan umbi-umbian menyebabkan jenis bahan pangan itu mudah diolah dan dikembangkan. Pengolahan hasil pangan yang bersumber dari 
umbi-umbian umumnya lebih sederhana seperti dikukus, diparut, dan digoreng. Yang paling umum dijalankan masyarakat adalah dikukus dan diparut untuk selanjutnya bisa dikonsumsi. Umbi-umbian seperti opa, opa larantuka, singkong ketan (lokal: kaujawa hengolo), manga, keladi, dan talas paling umum dikonsumsi dengan cara dikukus sebelumnya. Sementara biji-bijian biasanya dikukus dan direbus sebagai sayur atau makanan sampingan. Jenis makanan biji-bijian di antaranya kacang tanah, kacang panjang, jagung, kacang merah, palawija, dan padi.

Bentuk lain dari pengolahan pangan yang bersumber dari garis Wallacea adalah dengan merubahnya ke dalam bentuk lain. Sebagai gambaran, singkong beracun (kayujawa) bisa diubah menjadi kasoami setelah melalui pelepasan kulit, pemarutan, pemerasan, pengeringan, penggemburan, dan pengukusan dengan tingkat kematangan tertentu. Kasoami juga bisa dicampur dengan kacang merah yang telah direbus lebih dahulu. Kasoami juga bisa dipepe (dipukul-pukul/dibentuk) hingga membentuk balok namun tetap lembut dengan menambah minyak kelapa secukupnya. Untuk memberi rasa gurih dan bumbu, maka masyarakat setempat memberi bawang goreng di setiap sisinya (lihat gambar 3). Untuk beras dapat diolah tidak hanya menjadi nasi, akan tetapi bisa menjadi makanan tradisi, khususnya beras ketan. Beras ketan bisa dibuat luluta (nasi yang dimasak di bambu). Nasi ini mengikuti bentuk bambu bulat dengan campuran santan, bawang merah yang digoreng setengah matang, sedikit minyak, garam secukupnya, dan juga air. Untuk membakar nasi bambu ini sebelum dikonsumsi, maka dibutuhkan waktu yang relatif lama dan kayu bakar yang relatif banyak dalam proses memasaknya. Satu hal lagi adalah perlu menahan hawa panas dalam proses pembakarannya hingga benar-benar matang dan siap dikonsumsi. Nasi bambu yang diklaim sebagai makanan tradisi di Wakatobi di beberapa daerah dikenal dengan nasi lemang (Minangkabau) dan nasi jaha di Banggai dan Kepulauan Sula (Rabani, 2019). Di Nusa Tenggara Timur dinamakan dengan tapa kolo (https://travel.kompas.com/ $\mathrm{read} / 2014 / 11 / 16 / 090600227 /$ Tapa.Kolo.Makanan. Khas.Manggarai.Timur).

Ekspresi seni dalam sebuah media pangan atau makanan dapat dilihat pada tampilan bentuk jadi atau siap konsumsi pada sebuah makanan. Dalam kasus bentuk makanan di Wakatobi, sebagaimana tampak pada gambar 3, jelas menggambarkan hal itu. Pada bahan makanan berbasis singkong atau beras misalnya, tampak bahwa ruang kreatif untuk membentuk sebuah visual makanan lokal. Sentuhan seni yang berkelok dan mempunyai sudut yang presisi seperti putaran gelombang dan bersudut telah memperindah visual makanan yang kini menjadi makanan tradisi. Identitas makanan tradisi ini menguat ketika Wakatobi menjadi kabupaten sendiri pada tahun 2003 dan mengambil ikon budaya dan pariwisata berbasis maritim sebagai salah satu andalan untuk memperkuat identitas lokalnya. 

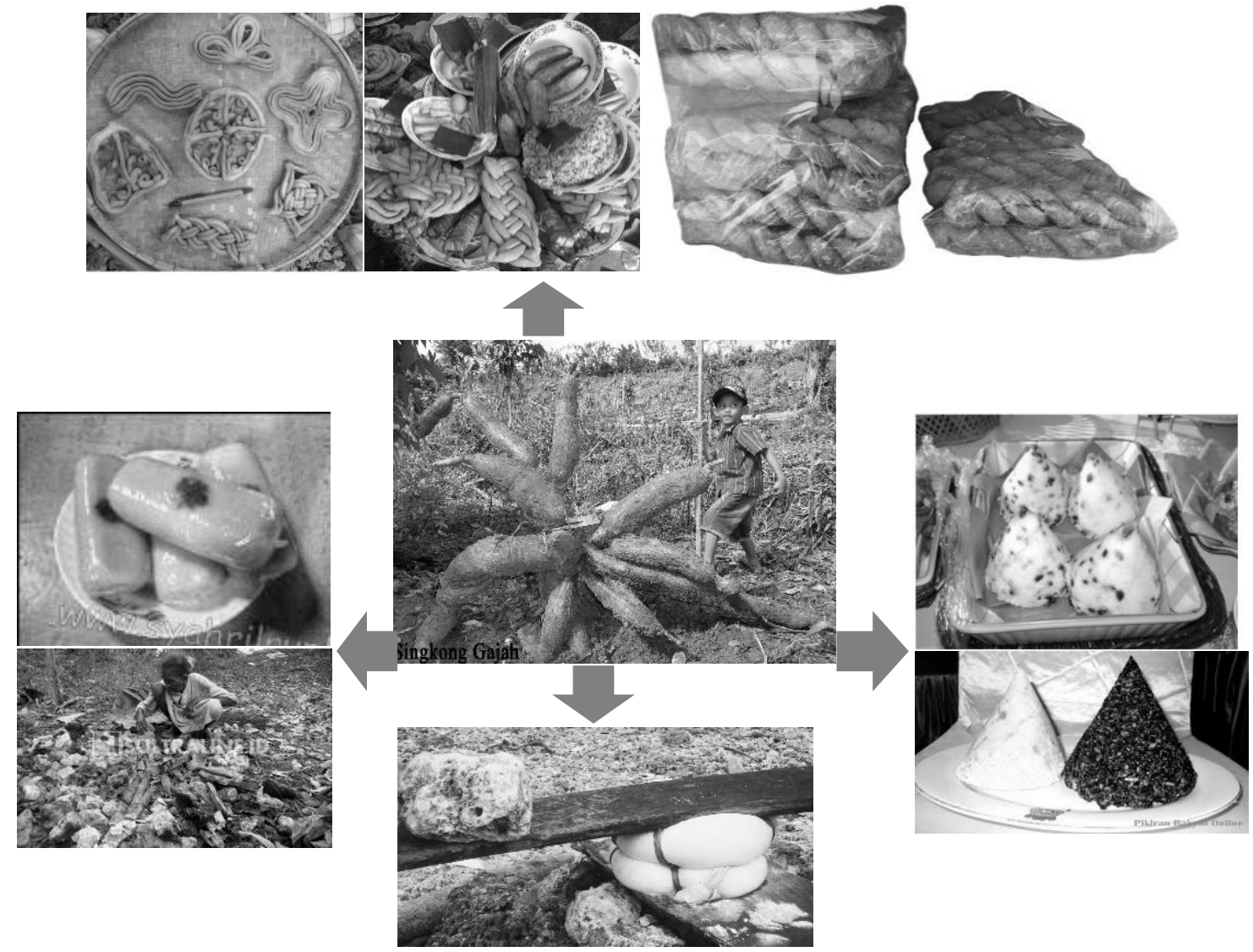

Gambar 3 Ragam sebagian dari bahan pangan dan bentuk kuliner yang ada di Wakatobi. Sumber: Koleksi pribadi

Dengan deretan gambar/visual yang merepresentasikan ragam bahan pangan olahan dari Wakatobi. Ubi kayu atau singkong dapat dibuat beragam makanan. Gulegule seperti pada gambar 3 di atas jelas telah mendapatkan sentuhan seni dan ekspresi masyarakat. Rangkaian, pola, dan model dengan komposisi yang seimbang. Bahan pangan dari kayu Jawa ini juga bisa dibuat dalam bentuk lain seperti hebatu. Singkong yang telah diparut dan dikeringkan dengan ditambah bumbu bawang dan garam

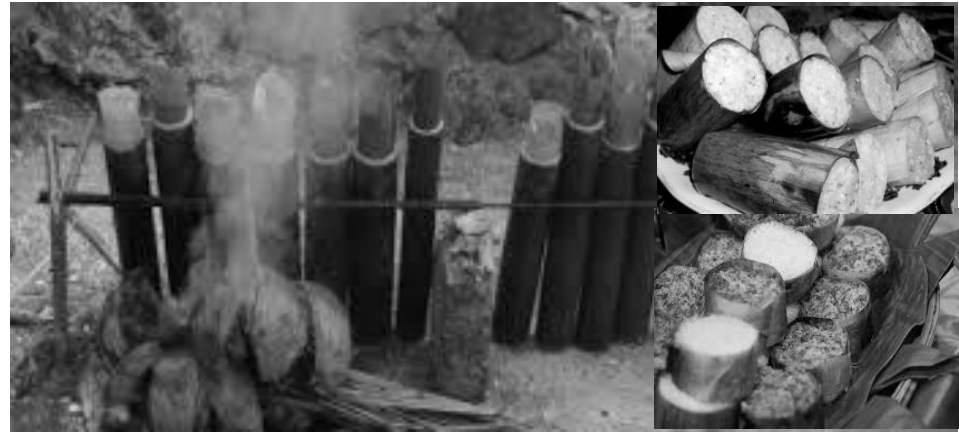

Gambar 4 Makanan Tradisi yang berbahan dasar beras Ketan. Sumber: Koleksi pribadi dimasak dengan bara batu yang dibakar dengan suhu tinggi. Selain itu (ka)soami, yang bisa dibuat dalam komposisi, yakni dipepe/dipukul hingga berbentuk lonjong, dan ditambahi sedikit minyak goreng dan bawang goreng. Ada lagi (ka)soami original yang berbentuk kubah dan putih. (ka) soami juga bisa 
dicampur dengan kacang merah untuk menambah gurih. Jenis yang disebut terakhir, bisa juga dimakan tampa lauk tambahan, karena cita rasanya diperoleh dari kacang merah yang bercampur dalam (ka)soami. Untuk (ka)soami yang berwarna hitam, bahannya berasal dari kayujawa yang dikeringkan. Kalau di Jawa, jenis seperti itu dinamakan dengan tiwul.

Bahan pangan yang berasal dari bugis adalah beras. Menurut catatan Nahdia (Nur, 2003; Nur et al., 2017), beras dari Bugis (Sulawesi Selatan) sejak abad ke-16 telah diperdagangkan ke Indonesia Timur. Beras dalam masyarakat Wakatobi diolah dengan beragam bentuk. Dalam perkembangannya, bahan pangan beras menjadi sumber pangan yang mewah, terutama beras pulut dan dengan harga mahal. Beras pulut (ketan) dibuat menjadi Lemang di Minangkabau, nasi Jaha di Manado, Bungku, Luwuk, Gorontalo, dan Manado, serta di Wakatobi dinamakan dengan luluta. Dahulu, beras ketan hanya dimakan oleh raja, jajaran perangkat adat, dan orang-orang berada (kaya).

Selain beras, bahan pangan yang berasal dari Kawasan Indonesia Timur yang didatangkan ke Wakatobi adalah Sagu. Orang Wakatobi mengolah sagu ke dalam bentuk papeda dan sinole. Makanan ini menjadi makanan yang selalu dibawa oleh para pelayar dari Kepulauan Maluku. Pembuatan Papeda, relatif mudah karena hanya dimasak dengan air panas, sedikit garam. Untuk menyajikannya, paling enak dengan kuah ikan parende. Ikan parende juga bisa disajikan dengan

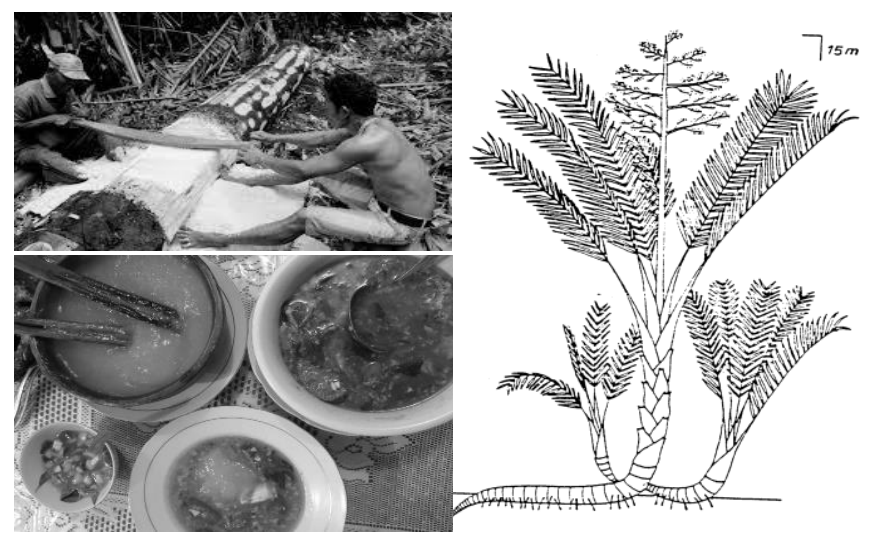

Gambar 5 Jenis Makanan yang berbahan dasar Sagu. Sumber: diolah dari google Image dengan kata kunci "Sagu" singkong, talas, dan opa rebus. Kuah dari ikan parende yang memberi cita rasa pada papeda, singkong rebus, karena sifat kuahnya yang menarik dengan campuran asam dan kunyit secukupnya, sebagaimana pada gambar di atas.

\section{PENGEMBANGAN SUMBER-SUMBER PANGAN DI WAKATOBI}

Muh. Nuh (2014) pernah mengatakan bahwa laboratorium terlengkap di dunia ada di Indonesia. Pernyataan Nuh itu mengingatkan keragaman yang ada di bumi Nusantara, di antaranya sebagian dari kondisi alam yang ada di dunia dapat ditemukan di Indonesia. Sebagai gambaran, untuk menemukan ciri khas dan karakter pasifik dapat dengan mudah kita temukan di Papua dan Nusa Tenggara. Demikian pula, bila ingin mengetahui sebagian budaya Asia Timur dengan mudah dapat menemukannya di kota- 
kota besar Indonesia seperti di Medan, Surabaya, Makassar, dan Jakarta. Apabila ingin mempelajari tradisi masyarakat Asia Barat, dengan mudah ditemukan di kota-kota besar yang mempunyai identitas kampung Arab (Rabani \& Artono, 2005). Demikian juga dari level peradaban manusia, di Indonesia terdapat peradaban yang hampir di setiap tingkatan ada, termasuk di dalam pengolahan bahan pangan.

Sulitnya perhubungan dan tidak semua wilayah berinteraksi dan terintegrasi dalam satuan kebudayaan Indonesia telah melahirkan perbedaan tingkat kebudayaan dan peradaban. Luasnya wilayah Indonesia yang terdiri dari puluhan ribu pulau dan dikelilingi laut luas menjadi sebagian dari penyebabnya. Demikian pula perbedaan pada kondisi alam dan geografisnya ikut mempengaruhi ketersediaan sumber daya pangan di masing-masing wilayah, termasuk pengolahan dan pengembangannya. Masalah semakin pelik ketika penduduk semakin bertambah di mana Wakatobi harus menerima pendatang dari luar wilayah sebagai konsekuensi kawasan itu sebagai tujuan wisata dan menjadi kabupaten yang tidak bisa menahan arus pendatang dari luar, khususnya pelaku usaha pariwisata, industri, dan investasi lainnya. Pekerja perusahaan yang didatangkan dari luar kepulauan juga ikut menambah jumlah penduduk sehingga persediaan pangan menjadi hal utama yang harus dipenuhi. Dalam konteks itulah, penting untuk memahami bagaimana Kepulauan Wakatobi mengembangkan sumber pangan lokalnya di tengah jumlah konsumsi yang semakin meningkat.

Sampai tahun 1990an, masyarakat Pulau Wangi-wangi masih menanam padi untuk dikonsumsi dan diperjualbelikan. Bibit padi ini umumnya didatangkan dari Baubau atau Lasalimu. Pada umumnya bibit padi juga berasal dari hasil panen sebelumnya yang disimpan berdasarkan musim, yakni ketika musim hujan sedang berlangsung. Penanaman padi hanya berlangsung 1 sekali setahun dan hanya pada musim hujan saja. Penanaman padi benar-benar berakhir ketika jaringan transportasi ke Baubau, Kendari, dan Makassar semakin lancar dan tidak tergantung lagi pada kondisi angin mason. Hal itu terjadi karena perahu dan kapal motor sudah dilengkapi dengan mesin berbahan bakar minyak. Beras dan bahan pangan lain dengan mudah mengalir ke Kepulauan Wakatobi.

Salah satu dampak dari kondisi itu adalah perubahan orientasi konsumsi masyarakat, dari kasoami yang berbahan dasar singkong menjadi nasi. Perubahan ini telah menggeser posisi pangan yang berbahan dasar singkong dengan padi, sehingga bahan pangan singkong turun kasta. Kemudahan dalam pengolahan sampai siap dikonsumsi menjadi alasan utama masyarakat memilih membeli beras siap konsumsi daripada harus mengolah singkong dengan banyak tahapan sebelum dikonsumsi. Jadi kepraktisan itulah dengan cepat mind set (pola pikir) masyarakat berubah, namun mengambil peran lain, yakni menjadi bahan makanan pelengkap dan diolah menjadi bahan baku untuk oleh-oleh. Peran baru singkong ini membuat penanaman atau budidaya terus berlangsung, meskipun tidak seperti sebelum Kepulauan Wakatobi 
menjadi Kabupaten di mana singkong saat itu masih menjadi bahan pangan utama masyarakat.

Pengembangan pangan yang berasal dari umbi-umbian masih dijalankan masyarakat. Hanya saja, umbi-umbian ini dikonsumsi secara terbatas karena sifatnya yang musiman. Tidak setiap saat bisa tersedia di pasar, sehingga mengkonsumsi umbiumbian ini juga terbatas. Selain itu, umbi-umbian seperti manga, talas, ubi jalar, keladi, jagung, kacang-kacangan, opa, opa Larantuka, dan sejenisnya tetap hanya sebagai pelengkap dari sumber pangan utama setelah beras dan ubi kayu atau singkong. Bahan pangan jenis umbi-umbian yang secara umum mengisi ruang makanan tradisi seperti kambalu, aru-aru (stick), dan senga-senga. Dua jenis makanan yang bahannya berasal dari umbi-umbian ini pengolahannya sebelum dikonsumsi adalah digoreng dengan minyak kelapa.

Dari sisi pangan hewani, terjadi perubahan yang semula berbasis ikan, berubah ke protein hewani yang berasal dari ayam potong. Budidaya ayam potong dilakukan masyarakat Wakatobi untuk memenuhi kebutuhan yang semakin meningkat. Berdasarkan data lapangan, produksi peternakan yang terus meningkat disebabkan oleh dua tiga faktor, yakni perubahan selera konsumsi penduduk karena lancarnya hubungan dengan pusat-pusat produksi ayam potong. Kedua, harga ikan yang tinggi untuk kebutuhan pesta yang terus bertambah. Pertambahan jumlah pesta berbanding lurus dengan penambahan jumlah konsumsi. Ketiga, penambahan kebutuhan makanan untuk kebutuhan perkantoran, khususnya untuk rapat dan kegiatan insidental dinasdinas pemerintah Kabupaten Wakatobi. Jadi ada penambahan frekuensi konsumsi yang sebelum menjadi Kabupaten, makanan tidak hanya tersedia di rumah tetapi juga disediakan oleh kantor karena penambahan dan perubahan waktu kerja (pengamatan lapangan).

Dengan kondisi seperti itu, maka sumber pangan di Wakatobi tidak cukup memenuhi kebutuhannya sendiri, melainkan harus mendatangkan sumber pangan dari daerah lain. Pertukaran menjadi jalan paling mudah dilakukan di mana dasar-dasarnya telah dilakukan sejak lama. Dasar historis berupa tersedianya fasilitas penghubung atau alat transportasi ke daerah lain tersedia dan setiap saat bisa digunakan bila dibutuhkan. Umumnya, para pedagang memberi andil besar dalam pemenuhan kebutuhan pangan di daerah itu, sehingga ketahanan pangan sejauh ini masih terus dipertahankan. Penulis menduga bahwa sejarah tahun 1960an di mana wilayah itu mengalami kekurangan pangan akut tidak boleh diulang di masa-masa kemudian. Dalam konteks itulah wilayah ini lebih penting tersedianya pangan penyanggah dari teknologi. Namun demikian pengembangan teknologi dibutuhkan untuk mengolah sumber daya, khususnya perikanan untuk menunjang pertukaran ekonomi dengan bahan pangan untuk warga kawasan ini. Bahan pangan di Wakatobi sejauh ini lebih mudah didatangkan dari Baubau, Kendari dan Makassar. Orientasi lebih baik membeli 
daripada menanam telah mereduksi jumlah petani yang berorientasi berkebun berubah menjadi pegawai atau karyawan. Hal itu berdampak pada generasi muda Wakatobi yang lebih memilih bekerja sebagai karyawan/pegawai atau merantau daripada menjadi petani atau berkebun di daerah sendiri, meskipun dalam kondisi ekologi yang terbatas.

\section{SIMPULAN}

Dua pesan yang disampaikan oleh data dalam makalah ini adalah korelasi yang kuat antara tidak tersedianya bahan pangan dengan bangunan tradisi pelayaran dan perdagangan menjadi pilihan rasional untuk dilakukan untuk memperoleh kebutuhan dasar yang tidak dapat diperoleh di Wakatobi. Dengan memanfaatkan jaringan pertukaran maritim, masyarakat Wakatobi mampu terintegrasi dengan sumber-sumber pangan yang lebih luas. Pangan tersebut oleh masyarakat setempat diolah sesuai pengetahuan mereka dan memberinya identitas dan sentuhan seni yang pada perkembangan kemudian bernilai tradisi. Interaksi dan mobilitas masyarakat di pulaupulau kecil telah menjadi dasar argumentasi tulisan ini bagi terjadinya jaringan pertukaran maritim. Keterbatasan sumber pangan, penduduk yang terus meningkat, dan alam pulau-pulau kecil yang tidak menunjang pemenuhan kebutuhan pangan menjadi elemen bagi berlanjutnya interaksi dan mobilitas masyarakat di Kepulauan Tukang Besi (Wakatobi). Dari titik itu, maka alasan ekonomi adalah yang paling menonjol, dan penguatnya adalah faktor politik, meskipun keduanya bisa saja berbeda jalan. Kepentingan ekonomi yang meliputi perbedaan alamiah dan sumber ekonomi menjadi pendorong terjadinya pertukaran ini. Ekspresi seni yang disematkan pada makanan yang beridentitas "tradisi" di Kepulauan Tukang Besi tidak terlepas dari upaya sakralisasi sebagai kelengkapan tradisi masyarakat di tingkat lokal.

\section{DAFTAR PUSTAKA}

\section{Artikel Koran}

De Sumatra post, 26 Mart 1931

\section{Buku dan Karya Ilmiah}

Barlagne, C., Bazoche, P., Alban, T., Harry, O.-L., Causeret, F., \& Blazy, J.-M. (2015). Promoting local foods in small island states: The role of information policies. Food Policy, 57(2), 62-72. https://doi.org/10.1016/j.foodpol.2015.09.003 
Boomgaard, P. (2003). In the Shadow of Rice: Roots and Tubers in Indonesian History, 1500-1950. Agricultural History, 77(4), 582-610.

Cleasby, N., Schwarz, A. M., Philips, M., Paul, C., Pant, J., Oeta, J., \& Kori, M. (2014). The socio-economic context for improving food security through land based aquaculture in Solomon Islands: A peri-urban case study. Marine Policy, 45(1), 8997.

Evers, H.-D. (1988). Traditional Trading Networks of Southeast Asia. Archipel, 35, 89100.

Grydehøj, A., \& Kelman, I. (2017). The eco-island trap: Climate change mitigation and conspicuous sustainability. Area, 49(1), 106-113. https://doi.org/10.1111/area.12300

Guillaud, D. (2015). Le vivrier et le sacré. Systèmes agricoles, rituels et territoires dans l'Est indonésien et à Timor-Leste (Food Production and Sacredness: Farming Systems, Land and their Ritual Management in Eastern Indonesia and TimorLeste). Archipel, 90, 245-274.

Hadara, A. (1987). Sistem Pelayaran dan Perdagangan Masyarakat Kepulauan Wakatobi: Tinjauan Kependidikan Sejarah. Univesitas Haluoleo.

Hadara, A. (2015). Gau Satoto dalam Perspektif Sejarah Wakatobi. In Asrif \& L. O. Usra (Eds.), Gau Satoto: Kearifan Lokal Orang Wakatobi (pp. 1-11). FramePublishing.

Hadara, dkk., A. (2014). Etnografi Suku-suku di Wakatobi. Mapan.

Hamid, A. R. (2010). Spirit Bahari Orang Buton. Ombak.

Juliana, L. (n.d.). Do Local Food Networks Foster Socio-Ecological Transitions towards Food Sovereignty? Learning from Real Place Experiences.

Leur, J. C. van. (1953). Indonesian Trade and Society, Essays in Asian Social and Economic History. Foris Publication.

Lutz, J., \& Schachinger, J. (2013). Do Local Food Networks Foster Socio-Ecological Transitions towards Food Sovereignty? Learning from Real Place Experiences. Sustainability, 5(11), 4778-4796. https://doi.org/10.3390/su5114778

Malihu, L. (1998). Buton dan Tradisi Maritim: Kajian Sejarah tentang Pelayaran Tradisional di Buton Timur 1957-1995 [Thesis]. Universitas Indonesia.

Nur, N. (2003). Produksi dan pemasaran beras di Sulawesi Selatan 1900-1943. Gadjah Mada.

Nur, N., Purwanto, B., \& Surjo, D. (2017). Perdagangan dan Ekonomi di Sulawesi Selatan, pada Tahun 1900-an Sampai dengan 1930-an. Jurnal Ilmu Budaya, 4(1), 617-712.

Pascali, L. (2017). The Wind of Change: Maritime Technology, Trade, and Economic Development. American Economic Review, 107(9), 2821-2854. https://doi.org/10.1257/aer.20140832

Rabani, L. O. (1997a). Migrasi dan Perkembangan Sosial Ekonomi Masyarakat Kepualauan Tukang Besi Kabupaten Buton 1961-1987. Universitas Gadjah Mada. 
Rabani, L. O. (1997b). Migrasi dan Perkembangan Sosial Ekonomi Masyarakat Kepulauan Tukang Besi Kabupaten Buton 1961-1987. Universitas Gadjah Mada.

Rabani, L. O. (2013, November 23). Melacak Jaringan Pelayaran dan Perdagangan Masyarakat Buton, Sulawesi Tenggara: Pendekatan Linguistik. Makalah dipresentasikan pada International Seminar on Linguistic and Language, Makassar.

Rabani, L. O. (2016). Penyelundupan dan Terbentuknya Kawasan Ekonomi Maritim Wakatobi Tahun 1980-an. Lembaran Sejarah, 12(2), 132-143.

Rabani, L. O. (2019). Commercial activities and development of the towns in the west side of Banda Sea Indonesia, early twentieth century. In Urban Studies: Border and Mobility (pp. 47-52). Routledge.

Rabani, L. O., \& Artono, A. (2005). Komunitas Arab: Kelangsungan dan Perubahannya di Kota Surabaya 1900-1942, :Vol. 7 No. 2 (2005). Jurnal Masyarakat Dan Budaya, 7(2), 113-129. https://doi.org/10.14203/jmb.v7i2.230

Shah, S., Moroca, A., \& Bhat, J. A. (n.d.). Shah, S., Moroca, A., \& Bhat, J. A. (2018). Neotraditional approaches for ensuring food security in Fiji Islands. Environmental development, 28, 83-100. Environmental Development, 28(Dec.), 83-100.

Statistik, B. P. (2016). Wakatobi Dalam Angka. Pemda Wakatobi.

Statistik, B. P. (2019). Kabupaten Wakatobi Dalam Angka. Pemda Wakatobi.

Stok, V. der (Ed.). (1922). De Zeeen van Nederlandsch-Indie. In Koninklijk Nederlandsch Aardrijkskundig Genootschap. Boekhandel En Drukkerij Voorheen E. J. Brill.

Tahara, T., Hamid, A. R., \& Siadi, L. O. A. G. (2015). Nilai Budaya Bahari Sabangka Asarope; Tradisi Pelayaran Orang Buton. Direktorat Sejarah dan Nilai Budaya, Direktorat Jenderal Kebudayaan Kemendikbud.

Utomo, Y. W. (2012, Mei). Wakatobi Jadi Cagar Biosfer Dunia. Kompas (Online). https://sains.kompas.com/read/2012/05/10/22210970/Wakatobi.Jadi.Cagar.Biosfer. Dunia

Wallace, A. R. (2010). Menjelajah Nusantara: Ekspedisi Alfred Russel Wallace abad XIX. , Remaja Rosdakarya.

Wibowo, A. (2015). Strategi Adaptasi dan Mitigasi Nelayan di Pulau-Pulau Kecil terhadap Dampak Perubahan Iklim. Studi Pustaka, 2(3).

Welzen, Peter C. van, Parnell, John A. N. dan Slik, J. W. Ferry. (2011). “Wallace's Line and plant distributions: two or three phytogeographical areas and where to group Java? In "Biological Journal of the Linnean Society" vol. 103, 3.

\section{Sumber Wawancara dan Website}

La Dimana 62 tahun, pelayar dan pedagang yang pengalamannya dimulai dari koki (juru masak) dan kemudian menjadi sawi dan menjadi pedagang. 
La Mananu, 70 tahun, Mantan Nakhoda Perahu puluhan tahun. Wawancara dilakukan di Wanci.

Tapa Kolo Makanan Khas di Nusa Tenggara. (https://travel.kompas.com/read/2014/ 11/16/090600227/Tapa.Kolo.Makanan.Khas.Manggarai.Timur). 